\title{
Historical Perspectives of Nutrition Science: Insights from Ayurveda
}

\author{
Veena, Vandana Verma*, Sangeeta Gehlot \\ Department of Kriya Sharir, Faculty of Ayurveda, IMS, BHU, Varanasi - 221005, Uttar Pradesh, \\ India; vandana.verma04@gmail.com
}

\begin{abstract}
:
Nutrition is the science that interprets the interaction of food in relation to maintenance, growth, health and disease of an organism. The history of nutrition science and dietetics can be traced back as far as history of civilization across the world. The food habits, cooking and food processing have been evolved with cultural development of human beings. The ancient physicians from Greek, Hippocrates, Galen, Plato, Chinese civilization and Indian physician of Ayurveda like Charak and Sushruta have duly recognized the importance of diet and dietetics along with physical activity in health and management of various disorders.

Although the advancement in nutrition science has added the discovery of various micronutrients and fortified food substances, still a large number of populations worldwide is suffering from disorders of malnutrition, food-borne diseases, neurotoxins and other non-communicable diseases due to wrong cooking, storage, packaging practices and intake of food in wrong combination. Ayurveda has advocated that to get the optimum benefits from the consumed food (Aahara), people should give due consideration to their psychosomatic constitution (Prakriti), state of digestive power (Agni), age, dietary rules, nature and combination of food etc.

It is very surprising fact that scientific development of nutrition science was started in between $18^{\text {th }}$ and $19^{\text {th }}$ century, but the researchers and academicians working in the field of nutrition and medicinal health science have not incorporated the valuable, time tested knowledge of Ayurveda, which could be applied for development of nutrition science, and will be helpful in treatment of diseases and maintenance of health too.
\end{abstract}

Keywords: Aahara, Ayurveda, Dietetics, Nutraceutical, Nutrigenomics, Nutrition

\section{Introduction}

Food is the basic need for all human being and intake of balanced diet is essential for proper growth, development and to remain healthy. The food habits, cooking and food processing have been evolved along with cultural development and evolution of human beings across the world, which could be seen in different ancient civilizations. The early period human was known as hunters and gatherers, who have taken food as raw meat of animal until the starting of agriculture i.e. approximately 1500
BC. The invention of fire developed culinary, processing, quality of food, storage and preservation of food.

The word dietetics was noted in the early writings of Hippocrates, Plato and Galen. The Greek term 'Diaita' means 'way of life' and the term 'diet' was used in this sense in treatises and handbooks until recent times in Europe $^{1}$. All the ancient physicians either from Greek or Ayurveda physicians of India believed that diet is the best way to treat a disease and intervention in the nutritional habits of the patient was a method of treatment. According to them, the regulation of diet is 
the physician's job par excellence. Although not officially recognized as a profession, dietetics and nutrition has constituted a branch of the medical art since the time of the ancient Greeks ${ }^{2-4}$.

Advent of modern technologies is not only helpful to discover nutrients but opened up new chapters in the history of nutrition and dietetics. After the discoveries of nutrients, it was realized that food is not only for quieting the hunger, but it is also required in proper quantity for nourishment of tissues and to remain healthy ${ }^{3}$.

Now a day's culinary, modes of public dining, dietary pattern and lifestyle are being changed leading to obesity and other non-communicable diseases. It can be reduced with systematic nutrition educational interventions on a massive scale. There is a need for adoption of healthy dietary guidelines, food cooking and processing along with strong emphasis on regular physical exercise. In this paper an attempt has been made to showcase and circulate the Ayurvedic knowledge related to nutrition and dietetics to the researchers and medical professionals. So that, the science of nutrition may be enriched as well as deficiency and over nutritional disorders can be managed in a better way by incorporating Ayurvedic measures of diet and dietary regulation.

\section{Aim and Objectives}

To review the history of food and nutrition science and analyze the possible contribution of Ayurveda in further development of dietetics and nutrition science in view of management of diseases and preservation of health in a better way.

\section{Materials and Methods}

A comprehensive literature search was done on the concept of food and nutrition, from standard text books of ancient Veda, Ayurveda and nutrition science, research articles, different online journals of standard e-databases like PubMed, PubMed Central and Google Scholar were searched to get relevant research papers related to the topics.

\section{Review and Discussion}

\subsection{Scenario of Food and Dietetics}

Literature reviews suggest that over the long period of time, there were many changes in the way humans have lived. The earliest humans were hunters and gatherers in their life, who took meat (richest source of protein) of animal as diet. The history of pre-farming era suggests (approximately 1500 B.C) that no or very little; wheat (bread/pasta), rice, milk, cheese, butter etc. was available in the human $\operatorname{diet}^{5}$. The people of early civilizations settled near rivers to fulfill the needed water for drinking and for their crops ${ }^{6}$. Previous studies have also suggested that with the advent of agriculture as an outcome of civilization, man acquired the ability to cultivate what he wanted, as by now he was influenced to some extent by the selection of the food that he wanted to eat. Homo erectus was known for use of stone tools and ability to make fire ${ }^{7}$. The invention of fire motivate people to eat cooked food then happened regular improvements in culinary, processing of food, and better quality of food, storage and preservation.

The selection of foods best suited for promoting good health has been found out by trial and error by continued use. Use of milks of different mammals as food for infants has been practiced from very early times ${ }^{8}$. Ayurveda has also described in detail about the classification of food on the bases of their origin, properties, comprehensive description of cereals, pulses, vegetables, fruits, different nutritional and medicinal uses of milk obtained from various animals, non-vegetarian diet, properties of various types of flesh (Mamsa) obtained from different animals, fishes.

\subsection{Food's Description from Ancient to Present Era}

\subsubsection{Pre Vedic Era-Ancient Civilizations}

- Pre Harrapan phase (7500-6000 BCE) known as early food producing era9

- Mohanjo-daro and Harappan civilization (2800-2500 B.C.): The description of cereals, household utensils, water supply and drainage system in this civilization suggest that the people of Harappan and Mohanjo-daro have the knowledge of food and nutrition ${ }^{5}$. 
- Chinese civilization has the earliest evidence of cultivated rice, found by the Yangtze River, is carbon-dated to 8,000 years ago ${ }^{10}$.

\subsubsection{Vedic Period (2000 BC)}

Food was known as the term Ida, Andha, Parimsa and Aahara. The food items like fruits, cereals, grains, pulses, milk and milk products were used in this period. Diet was associated with divine attributes and emphasized as the "life giver".

\subsubsection{Rigveda}

Food is called as 'Anna' derived from "ad" (to eat) and 'pitu' (in the sense of nourisher). Dairying was well developed, fermented (Soma) and alcoholic (Sura) drinks were consumed suggesting an advanced level of food preparations; the art of cooking, the method of cleaning food with a sieve and grinding, food-grains viz. barley, rice, lentils and preparation of khichadi, cake (Аpupa) etc. and the use of implements and utensils ${ }^{5,11,12}$.

\subsubsection{Shukla Yajurveda}

There is description about the sacred diet, which was offered to the Gods with the recitation, "O forefather in heaven may you receive the energetic milk, ghee, sugar candy, ripen fruits and pure water offered by $\mathrm{me}^{\text {"13. }}$.

\subsubsection{Atharvaveda}

The prepared food like the rice cooked with water, ghee and mixed with juice of soma is the diet of Brahman, which is called "Brahmodana"14.

\subsubsection{Upanishad (800 to 400 B.C.)}

- Upanishad advocated the universal dietetic regimen in ancient civilized society. Here the teacher and student together to pray to God, chanting "O, God we may live together, eat together, there should not be any hatred and egoism among us. We may enjoy the healthy lives and live peacefully together" 15 .

- Taittiriya Upanishad - The "Anna" has been recognized as a great entity for life. Anna is known as "Brahma" as all the animates are produced from Anna, maintained by Anna and at the end assimilate in the Anna ${ }^{16}$.
- Chandogya Upanishad laid more emphasis on purity of food and its effects on body and mind ${ }^{17}$.

- Manusmriti also laid more importance on food and advocated certain psychic discipline on the part of its user. It has been described that one should always praise the food but not to abuse it and by seeing the food everyone should get delighted ${ }^{13}$.

- Yajnavalkya Smriti stated that one should think the diet as nectar and should take it with devotion. Thus, it maintains the body well and destroys the sin (diseases) ${ }^{13}$.

\subsubsection{Mahabharata (300 B.C.)}

There had been many developments in dietetic field. A famous king Nala, had established a science of dietetic named "Nalapakavidhi"13. Dairying was well developed; fermented (Soma) and alcoholic (Sura) drinks were also consumed, suggesting that an advanced level of food preparations had developed ${ }^{5}$.

- Bhagavad-Gita (200 BCE): It dealt with the salient characteristics of diets, which has been accepted as a source for creation of life. In $17^{\text {th }}$ chapter three types of diet viz. Sattvika, Rajasika and Tamasika have been dealt separately and their responses on the body have been well recognized ${ }^{13}$. Sattvika food denotes for prosperity, longevity, intelligence, strength, health and happiness, includes fruits, vegetables, legumes, cereals and sweets. Rajasika food, signifies activity, passion and restlessness, includes hot, sour, spicy and salty foods. Tamasika food is intoxicating and unhealthy ${ }^{18}$.

\subsubsection{Physicians of Greek}

- The name of Greek physician Podalirius is mentioned in Homer's epic ( $8^{\text {th }}$ Century BC) 'The Iliad', was recognized for his special interest in dietetics ${ }^{3,4}$.

- Pythagoras (570 BC-495 BC) a philosopher, mathematician, was also considered to be "the Father of Ethical Vegetarianism". He believed that in order to obtain the highest level of spiritual and physical health, it was necessary to follow a lifestyle that included a vegetarian diet which excluded meats and other flesh foods. 
- Anaxagoras (500 BC-428 BC) reasoned that food became the human body and hence must contain 'generative components' termed by him 'homeomerics'19.

- Hippocrates (460-370 BC) presented his concepts on nutrition and role of diet in the treatment of disease in his treatise 'on diet' and many remarks of the entire Hippocratic work (Corpus Hippocraticum) lucidly reveals the importance of the nutritional choices in human nosology and therapeutics. He wrote "Let thy food be thy medicine, thy medicine be thy food," It was suggested that the persons who are naturally very fat are apt to die earlier than those who are slender" $3-4,20-21$.

- Plato (460-348 BC) suggested that the therapeutic approach to human diseases should be made through the regulation of diet rather than with medication, "Wherefore one ought to control all such diseases, so far as one has time to spare, by means of dieting rather than irritate a fractious evil by drugging" (Timaeus verse $89 \mathrm{C}-\mathrm{D})^{4,20}$.

- Galen (130-200 AD) prominent Greek physician, surgeon and philosopher in the Roman Empire has highlighted the importance of diet in maintaining health and the treatment of diseases in his dietary treatise "On the power of food". He was one of the believers in diet, and said "health depends chiefly on the choice of food." Galen insists that balance of the four humors can be beneficially or adversely affected by diet. He stressed the therapeutic value of climate and a full diet for tuberculosis and emphasized the value of milk in the treatment of disease ${ }^{22}$.

- Athenaeus (200-300 AD) recorded many of the nutritional habits of the classical era of Greek antiquity in his work entitled 'Deipnosophists'. Boorde (16 ${ }^{\text {th }}$ Century) English traveller, physician and writer wrote two short books related to health, 'Breuyary of helth and acompenyous regiment or a dyetary of helth' He included brief chapters on bread, soup (Potage), meat, eggs and cheese, fish and fowl, roots, herbs, fruits and spices and diets for the following: Sanguine, phlegmatic, choleric and melancholic temperaments and pestilence, fever, gout, leprosy, consumption, palsy, madness and dropsy $^{20}$.

\subsubsection{Ayurveda Physician and Scholars: Concept of Food and Dietetics in Ayurveda}

- The scholars of Ayurveda, Atreya (1000 B.C.), Charak/ Agnivesha (400 and 500 BC), Sushruta (400 to 1000 BC), Vagbhata (600 BC), Bhava Mishra (1550 A.D.) have given vivid description about diet, dietetics and nutrition long ago before the discovery of nutrients and foundation of nutrition science. A comprehensive description of food (Aahara) for getting proper nutrition, prevention and management of a wide range of disorders is found. Whatever is voluntary eaten with mouth or ingested is called Aahara ${ }^{23}$. It has also been considered as basis of life (Prana) and used in two meanings i.e. the act of food intake and for food items. Diet is known as important pillar in sustenance of life and health. Ayurveda has considered food (Aahara) as a chief drug (Mahaaushadha) and believes that health and disease both are the product of nutrition. Food or diet is an important item to provide energy and regulates all human biological function i.e. life process, growth, repair and maintenance ${ }^{24}$. The principle of dietetics and nutrition in Ayurvedic system of medicine includes different classes of Aahara i.e. eating and drinking items, principle of wholesome and unwholesome diet (Pathyapathya), discipline of eating (Ashtha Aahar Vidhi Visheshayatana, Dwadasha Ashana Vidhi etc.), incompatible diet (Viruddha Aahar), the diet and lifestyle behavior in preconceptionally and pregnancy period (Gharbini Paricharaya), conduciveness and unconducive diet (Satmayata and Asatmayata), diet as per psychosomatic constitution [Prakriti (Vata, Pitta, Kapha)], age, diseases and their stages, therapeutic diet, seasonal diet (Ritu), balanced diet, six Rasa (Shadarasa), required properties (Gunas), digestive power (Agni), digestive system (Kostha) ${ }^{24}$. These valuable descriptions could be applied for development of nutrition science and will be helpful in treatment of diseases and maintenance of health too.

\subsection{Classification of Food}

Ayurveda has included all the components of balance diet and described the classification of food (Aahara Varga), which is similar to food classification stated in nutrition, for example - food science narrated macro and micronutrient (carbohydrate, protein, fat, vitamins, 
minerals, water). Ayurvedic texts classify food as Aahara Varga. The different group (Varga) are cereals (Shuka), pulses (Shamidhanya), flesh (Mansa), vegetables (Shaaka), fruits (Phal), ginger, garlic, onion, radish, lime (Harita), beverages (Madya), milk and milk products (Gauras), sweet products obtained from sugarcane (Ikashu), oil, ghee, salt, alkali, cumin, celery, coriander, bay leaf, ginger, pepper, hingu (Aaharaopayogi). Adjuvant of food (Aaharaopayogi Dravya) makes food tasty and appetizer, alleviates Vata and Kaphadosha, foul smell. Cereals and legumes are recommended for use when they are one year old as new one is heavy (Guru) in digestion while old is easy in digestion ( $\mathrm{Laghu}$ ). The crop which comes shortly is regarded as lighter. The legumes when dehusked and properly fried digest easily ${ }^{25}$.

There are many other ways of classification of diet (Aahara):

- According to origin - animal origin (JangamDravya) and plant origin (Sthavar Dravya).

- According to effect - wholesome (Hitakar) and unwholesome (Ahitakar Aahara).

- According to use - solid (Bhakshya), semisolid (Lehya), drinking (Ashan and Paan).

- According to taste - sweet (Madhura), sour (Amal), saline (Lavana), pungent (Katu), bitter (Tikta), astringent (Kashaya).

- According to quality - light-heavy (Guru-Laghu), cold-hot (Sheeta-Ushna), unctuous-rough (SnigdhaRuksha), slow acting-fast acting (Manda-Tikshana), immobility-mobility (Sthir-Sar), soft-hard (MraduKathin), nonslimy-slimy (Vishad-Pichchila), smoothness-roughness (Slakshana-Khar), minutelarge (Sukshma-Sthul), solidity-fluidity (SandraDrava $)^{26}$.

\subsection{Wholesome and Unwholesome Diet (Pathya Apathya)}

Pathya is compatible for bodily channels and mind. Apathya is opposite of Pathya. Wholesome food promotes the growth of person and unwholesome food is cause of disorders. Pathya-Apathya has opposite effects due to the variation in dose (quantity), time, origin, action, soil, pathology, body and Dosha ${ }^{27}$.

Acharya Charaka has given a list of food items which should be and should not be taken regularly. Wholesome food can be taken regularly are Rice variety which gets ripened in 60 days (Shali). Vigna radiata (Mudga), Rock salt, Jangala Mamsa (Meat of animals of arid, desert-like land), Punica granatum (Dadima), Seed of bamboo tree, Phyllanthus emblica (Amalaka fruits), Hordeum vulgare (Barley), Rain water, Milk, Ghee, Honey, Vegetables like Capsicum annum (Chili), Chenopodium album (Vastuka), Blepharis edulis (Sunisannaka), Leptadenia reticulata (Jivanti), Amaranthus spinosus (Tanduliyaka), Centella asiatica (Mandukaparni) ${ }^{28}$.

\subsection{Unwholesome Food Items}

Heavy food substances (Guru Aahara Dravya) such as dried meat (Vallura), dried vegetables (Sushkashaka), lotus rhizome, lotus stalk, meat of diseased animals, boiled buttermilk (Kurchika), coagulated milk (Kilata), pork, beef, meat of buffalo, fish, curd, black gram (Masha) and pounding barley to remove chaff and then boiling the grain in water or milk (Yavaka) should not be taken regularly. Curd shouldn't be taken at night ${ }^{28}$.

Ayurveda already noted that excess intake of food viz. milk-ghee, jiggery food items, rice with sedentary work, is cause of many disease i.e. diabetes, obesity, fever, leprosy etc.

\subsection{Therapeutic Diet}

Diet as per diseases narrated in Ayurveda like in obesity (Sthaulya) and diabetes (Prameha Chikitsa) like Terminalia chebula (Harad), Triphala, honey (Madhu), use of butter milk (Takra), Hordeum vulgare (Barley), and Vigna radiata (Mudga) in Grahni, plies, fistula, use of pulse of Kulattha in kidney stones (Ashmari). To increase weight food curd, milk, ghee, meat, newly grown wheat and rice ${ }^{29}$.

\subsection{Incompatible Diet (Virrudha Aahara) ${ }^{30,31}$}

\subsubsection{Desha (place) Viruddha}

Use of rough and sharp substances in arid zone (Jangle) and unctuous and cold in marshy region (Anupa).

\subsubsection{Kala (time) Viruddha}

Intake of rough and cold food in the winter and pungent and hot food in the summer. 


\subsubsection{Agni (power of digestion and metabolism) Viruddha}

Cardamom in coffee, radish mixed with banana, melons with dairy.

\subsubsection{Matra (quantity) Viruddha}

Honey mixed with ghee in equal quantity.

\subsubsection{Satmya (wholesome) Viruddha}

Person accustomed of sweet and cold but antagonism in suitability to pungent and hot.

\subsubsection{Dosha Viruddha}

Use of diet, drug and behavior similar to Doshas in properties.

\subsubsection{Sanskar (mode of preparation/processing) Viruddha}

Peacock's meat attached to the castor stick, heated honey.

\subsubsection{Veerya (potency) Viruddha}

Sheetaveerya and Ushnaveerya substances combined together, fish with milk.

\subsubsection{Koshtha (bowels) Viruddha}

When too little of mild potency and non-breaking drug is administered in those who are having hard bowels and while heavy, breaking and abundant one is administered in those who are having soft bowels.

\subsubsection{Avastha (state of health) Viruddha}

Vata vitiating substances are giving to the person who indulge in overwork, sexual intercourse and exercise and Kapha vitiating one in that indulged in oversleep and laziness. it is antagonism in respect of health condition.

\subsubsection{Kram (sequence/order) Viruddha}

Intake of food before excreting faeces and urine and without appetite or excessive hunger, consuming curd at night, taking Madhura Rasa food or Dravya at the end of meals and Tikta and Katu Rasa Dravyas (food substances) at the starting of meals, hot water after taking honey.

\subsubsection{Parihar (contra indication) Viruddha}

Consuming cold water immediately after having hot tea or coffee, hot things are taken after intake of pork or cold after intake of ghee.

\subsubsection{Upachar (treatment) Viruddha}

Cold drink after taking ghee

\subsubsection{Paak (cooking) Viruddha}

Cooking on damaged or bad fuel or the grains is uncooked, overcooked or burnt.

\subsubsection{Samyoga (combination) Viruddha}

Sour things taken with milk, fruit salad or milk with banana, milk with apple.

\subsubsection{Hridaya (palatability) Viruddha}

Taking unlike things.

\subsubsection{Sampad (richness of quality) Viruddha}

Immature, over mature or damaged Rasa in a substance.

\subsubsection{Vidhi (rules for eating) Viruddha}

Food is not taken in privacy ${ }^{32}$.

Harmful effects of incompatible foods - Disorders after having incompatible foods in diet can be impotency, blindness, erysipelas, ascites, pustules, insanity, fistulain-ano, fainting, necrosis, tympanitis, spasm in throats, anemia, Ama Visha (harmful metabolites produces after incomplete digestion), leukoderma, leprosy, Grahaniroga, oedema, acid gastritis, fever, rhinitis, genetic disorders and even death ${ }^{30}$.

\subsection{Eight Specific Considerations for Diet and Dietary Intake (Ashtha Aahara Vidhi Visheshayatana) ${ }^{33}$}

\subsubsection{Prakriti (Original Qualities of Food)}

Heavy food- black gram, pork, dry fruits, egg etc. Light food - green gram, meat of deer, green vegetables, etc. 


\subsubsection{Karana (Producing Specific Qualities by Processing and Cooking of Food)}

Various method and techniques of food processing; contact of water, soaking, fermentation, churning, peeling and contact of fire etc.

\subsubsection{Samyoga (Food Combination)}

Honey and ghee, fish and milk, honey and aloe vera, cereals and pulses, milk and yoghurt etc.

\subsubsection{Rashi (Quantity)}

Total quantity of meal (Sarvagraha), quantity of individual ingredient (Parigraha).

\subsubsection{Desh (Place of Origin of Food)}

Food grown in different places (soil) has different properties.

\subsubsection{Kala (Time Factor)}

Meal should be taken in proper time after certain interval.

\subsubsection{Upayogasanstha (Rules of Intake)}

One should take diet when previous taken meal is digested, not too little or not too much taken meal etc.

\subsubsection{Upayokta (User)}

The person should follow certain rules while taking meal.

\subsection{Rules of Taking Meal (Dwadasha Ashana Pravicharana)}

- One should eat warm, unctuous food, in proper quantity after due consideration to the self at pleasant place with all the favorable accessories when the previous food is digested. One should take food with full concentration, not too fast, not too slow, no talking or laughing during food intake. Food combination should be non-antagonistic ${ }^{34-35}$.

- Agni the prime determinant of quantity of food: Ayurveda has advocated that the quantity of diet should be determined as per the status of digestive power (Agni) of an individual, "Aaharamatratu Agnibalapekshani". To maintain the functional state of fire (Agni), one should take heavy food as one third or half of the saturation point and not excessive saturation even in case of light food ${ }^{36}$. The status of bio-fire also depends on the level of physical activity of an individual. So, for the regulation of digestive power and metabolism, Ayurveda has advised for some kind of physical activity (Vyayama) in daily routine ${ }^{37}$.

\subsection{Role of Diet in Determination of Psychosomatic Constitution (Prakriti) and Fetal Development}

Diet is an important factor that affects determination of Prakriti of new born baby and its development. Pumsavana $\mathrm{Karma}^{38}$ has been described for getting the desired child as the term of measure which helps in procreating male progeny (Pumsavana) with Karm and Vidhi. Food plays a very important role in this process ${ }^{39}$.

Desires expressed to eat different kind of meat by the pregnant mother are indicative of following probable characters of a child (Table 1$)^{38}$.

Table 1. Desires to eat different kind of meat by the pregnant and the probable characters of a child

\begin{tabular}{ll}
\hline $\begin{array}{l}\text { Desire to eat different } \\
\text { kind of meat }\end{array}$ & Characters of the child \\
\hline $\begin{array}{l}\text { Meat of iguana } \\
\text { (type of reptile) }\end{array}$ & $\begin{array}{l}\text { Sleepiness and that whose nature } \\
\text { consists in eating itself or does } \\
\text { not express his desire. }\end{array}$ \\
Cow's meat & $\begin{array}{l}\text { Mighty and with good endurance. } \\
\text { Brave, red eyes and excessive } \\
\text { buffalo's meat }\end{array}$ \\
Hog's meat & $\begin{array}{l}\text { Sleepy, brave or bold. } \\
\text { Industrious, swift runner and } \\
\text { always moves in forests. }\end{array}$ \\
Deer's meat & Terrified or anxious. \\
Meat of Srmara & Poltroon. \\
(big deer) & \\
Meat of partridge &
\end{tabular}

\subsection{Diet in Pregnancy ${ }^{40-41}$}

The monthly dietary regimen is advised for pregnant women after conception, what should eat or not to eat, for over the pregnancy.

First month: Milk, sweet, cold, liquid diet, congenial diet.

Second month: Sweet, cold, liquid diet, milk medicated with Madhura drugs e.g. Kakoli.

Third month: Milk with honey and Ghrita, sweet, cold, liquid diet, specially cooked a variety of rice 
(Shasthi) with milk, olio prepared with rice and pulse (Krshara).

Fourth month: Butter extracted from milk in the quantity of one Aksha or milk with butter, cooked Shasthi rice with curd, dainty and pleasant food mixed with milk and butter and meat of wild animals, medicated cooked rice.

Fifth month: Ghrita prepared with butter extracted from milk, cooked Shashti rice with milk, meat of wild animals along with dainty food mixed with milk and Ghrita, rice gruel (Yawagu), rice cooked with milk and sweetened (Payasa).

Sixth month: Ghrita (prepared from milk) medicated with the drugs of Madhura group, Ghrita or rice gruel medicated with Gokshura plant, sweetened curd.

Seventh month: As same as in sixth month, Ghrita medicated with group of drugs (Vidarigandhadi) like Shatavari, Kantakari, Vidarigandha, Sariva, Prithakparnyadi etc., a sweet dish (Ghritakhanda).

Eighth month: Rice gruel prepared with milk and mixed with Ghrita, use of liquid diet prepared with Ghrita and milk.

Ninth month: Meat soup with cooked rice and fat (preferable Ghrita) or rice gruel mixed with good quantity of fat, Harita opines in ninth and tenth month different varieties of cereals should be used.

\subsection{Developments in Nutrition Science}

Nutrition gained recognition as a scientific discipline, with roots in physiology and biochemistry by applying the scientific method. Various discoveries of nutrients have been held from year 1770 to 1968 years and the first discoverer, Antoine Lavoisier is known as the "Father of Nutrition and Chemistry" after him, many experiments conducted to discover other nutrients by different scientists, scholars and physicians. But it is considered that the science of nutrition rediscovered by the discovery of vitamins between two world wars ${ }^{42}$.

In recent time the concepts of nutrition science have been explored in some new areas like food additives, food technology, bio fortification, food chemistry, food safety and nutritional genomics, which have also been implemented in different nutritional program and policies for improvement of health.
The recent development in nutrition science may be conveniently discussed under the following heads:

- Recent areas in nutrition which originated for the improvement health, prevention and mitigation of diseases i.e. nutraceutical, nutrition genomics which encircles two disciplines; Nutrigenetics and Nutrigenomics. Ayurveda, practiced for thousands of years, which evolved around the concept of preventive and personalized medicine by maintaining a balance of the three biological entities, called Tridosha namely Vata, Pitta and Kapha ${ }^{43}$.

- Nutrigenetics: It aims to understand how the genetic makeup of an individual affect the response to diet and it considers underlying genetic polymorphisms ${ }^{44}$. Nutrigenetics embodies the science of identifying and characterizing gene variants associated with differential responses to nutrient and relating this variation to disease states.

- Nutrigenomics: It describes the use of functional genomic tools to probe a biological system following a nutritional stimulus that will permit an increased understanding of how nutritional molecules affect metabolic pathways and homeostatic control ${ }^{44}$.

- Nutraceutical: It can be defined by functional food that provides all nutrients in required amount and this type of food acts in the prevention or treatment of disease or disorder other than anemia called nutraceutical ${ }^{45}$. Nutraceuticals give health benefits by acting as anticancer agents, antioxidant and antiinflammatory activity, influencing positively on blood lipid profile and bone protective by increasing the action of estrogen. Nutraceuticals combine nutrition and pharmaceuticals to mean that food extracts can be used as preventive drugs or food supplements examples are dietary supplement (vitamins, minerals, fiber, fatty acids and amino acids); chia, honey, fish oil, cod liver oil, herbs; Ocimum tenuiflorum (tulsi), Thymus vulgaris (ajvine flower), Petroselinum crispum (ajmoda), Rosmarinus officinalis (rosemary), Coriandrum sativum (coriander), Anethum graveolens (dill weed), Curcuma longa (turmeric), Azadirachta indica (neem), fruit and vegetables; Daucus carota (carrots), Mangifera indica (mangoes), Citrus sinensis (oranges), Vitis vinifera (red grapes), Cucurbita (pumpkin), Prunus 
domestica (plums), Solanum lycopersicum (tomato), Actinidia deliciosa (kiwi fruit) etc. ${ }^{46}$.

To spread the awareness of nutrition among population, the people has begun many nutritional academy, associations or institutions, nutritional software, health and care guide, health information library, nutrition foundation of India, nutrition and weight maintenance and also explained types of diet for the healthy and when people become diseased, the diet are - like Sippy's diet, Andersen diet, Meulengracht diet and Bland diet for peptic ulcer patient, Karell diet for heart disease, Portfolio diet for atherosclerosis patient etc. ${ }^{47}$.

\subsection{Dietetics Education in India}

Dietetics was introduced firstly as a subject in undergraduate curriculum of Women's Christian College, Madras by Mason Eleanor in 1942 in India. Later Dorothy Pearson developed a lecture demonstration course on diet therapy. A postgraduate course in institution management and dietetics was introduced in 1956 under the U.S. technical cooperation mission and government of India project. The kitchen units of some government hospitals were renamed as the dietary department and the supervisor was designated as Dietitian. In Calcutta, All India Institute of Hygiene and Public Health started a diploma course in dietetics in 1949. This was later the venue for the birth of the Indian Dietetics Association $1963^{48}$. Different association of nutrition have been started up in the different countries like Australia, Canada, South Africa, American, Japanese, British, Indiana, Ghana, which represents and develop the dietetic profession to contribute towards achieving optimal nutrition and registered dieticians ${ }^{3}$.

\subsection{Establishment of Health Programs in India}

After the discovery of nutrients, the health programs were established for the health improvement of the people after independence of India. The central government launched national health programs for the control of the communicable diseases, improvement of environmental sanitation, raising the standard of nutrition, control of population and improving rural health. Numbers of international and foreign agencies have been set up i.e. WHO, UNICEF, UNFPA, world bank and foreign agencies are SIDA, DANIDA, NORAD, USAID are providing technical and material assistance in the implementation of the programs. In recent $12^{\text {th }}$ five-year plan data have shown that Non-Communicable Disease (NCD) is the main reason of nearly half of all deaths in India ${ }^{49}$.

The programs have been established for the improvement of the nutritional status, to reduce malnutrition and overcoming specific deficiency disease of the population of India, which are- Vitamin A prophylaxis program, Prophylaxis against nutritional anemia, Iodine deficiency disorders control program, Special nutrition program, Balwadi nutrition program, ICDS program, Mid-day meal program, Mid-day meal scheme, National food security act 2013 and so on ${ }^{50}$.

\section{Conclusion}

Based on this discussion, we can conclude that the awareness of diet and dietary habits play a key role in maintenance of health, treatment and control of many diseases. The nutrition science is still developing and yet not scientifically explored all the factors which affect the nutrition and health. Whereas Ayurveda has very comprehensive description considering all the possible factors affecting the nutritional quality of food, nutrition of body in health as well as in disease. Ayurveda also has its unique descriptions regarding food, dietary combinations, food processing and cooking, rules regarding intake of nutrients for proper nutrition, incompatible diet etc. Ayurveda principles can be applied for development of nutrition science, which will be helpful in improvement of health, prevention and treatment of diseases.

\section{References}

1. Cannon G. The rise and fall of dietetics and of nutrition science. 4000 BCE-2000 CE. 2005; 8: 701-5.

2. Roggi C, Centrale O, Cena H, Roggi C, Lucchin L, Turconi G. Health nutrition practice in Italy. Nut Rev. 2010 Sep; 68(9): 556-63.

3. Koleilat M. Dietetic practice: The past, present and future. East Mediterr Health J. 2004 Nov; 10(6):716-30. 
4. Skiadas PK, Lascaratos JG. Original Communication Dietetics in ancient Greek philosophy: Plat 's concepts of healthy diet. 2001. p. 532-7.

5. Manyam V. Food, dietetics and nutrition in ancient India. Bull Ind Inst Hist Med. 1995; 25: 79-99.

6. Beginnings and Early Civilizations (10,000-1000 BCE). 2017. p. $1-5$.

7. Garn SM, Leonard WR. What did our ancestors eat? Nutr Rev. 1989; 47(11): 337-45.PMid: 2689923. https://doi. org/10.1111/j.1753-4887.1989.tb02765.x

8. Swaminathan M. Food and Nutrition. second. Bangalore: The Bangalore Printing and Publishing Co., Ltd.; 2000. p. 1-5.

9. Wright R. Periodisation of the Indus Valley Civilisation. 1971. p. 9-14.

10. Poon L. History of China. Hist China. 2009.

11. Trivedi RG. RG-Veda-Samhita. Varanasi: Chowkhamba Vidyabhawan Varanasi; 2007. p. 281-2.

12. Sarkar P, Lohith KDH, Dhumal C, Panigrahi SS, Choudhary R. Traditional and Ayurvedic foods of Indian origin. J Ethn Foods. 2015; 2(3): 97-109. https://doi.org/10.1016/j. jef.2015.08.003

13. Trupti J. Study on viruddha-āhāra and its relevance in causation of diseases. Banaras Hindu University; 2008.

14. The Introduction Mantras, The They, Atharva Each, Sama Brahmanas, The Samhita, Rgveda.

15. Pansikar Vashudev Laxaman. Kathopnisat. Ishaghstottarsatopnisadha. Varanasi: Chowkhamba Vidyabhawan Varanasi; p. 4.

16. Pansikar Vashudev Laxaman. Taittriopnisad, Bhraguvalli. Ishaghstottarsatopnisadha. Varanasi: Chowkhamba Vidyabhawan Varanasi; 2002. p. 26.

17. Pansikar Vashudev Laxaman. Chandogyopanioad. Ishaghstottarsatopnisadha. Varanasi: Chowkhamba Vidyabhawan Varanasi; 2002. p. 60.

18. Agrawal MM. Sri Madbhagvad Gita. 7-10 V editor. Delhi: Chaukhambha Sanskrit Pratishthan; p. 766-9.

19. Nutrition G, Nutrition N, Nutrients N. Lesson 1 : Nurition, History of Nutrition Unit 1:1-4.

20. Koleilat M, Hwalla N. Dietetic practice: The past, present and future. East Mediterr Heal J. 2004; 10(4): 716-29. PMid: 16335757.

21. Todhunter E, Darby W. Guidelines for maintaining adequate nutrition in old age. Geriatrics. 1978; 33(6): 49-51. PMid: 648878.

22. Food and diet in ancient medicine. 2018. p. 2-5.

23. Sharma PV. Charak Samhita of Agnivesha. Reprint ed. Varanasi: Chaukhambha Orientalia; 2008. p. 166-7.

24. Singh S. Principle and practice of nutrition and dietetics in Ayurveda. Int J Res Pharm Biosci. 2015; 2(7): 1-7.
25. Sharma PV. On the type of food and drink: Group of awned cereals. Caraka Samhita. Reprint Ed. Varanasi: Chaukhambha Orientalia, Varanasi; 2008. p. 194.

26. Sastri K, Chaturvedi GN. Sutrasthanam. Sastri R, editor. Charak Samhita. Varanasi: Chaukhambha Bharati Academy Varanasi; p. 465.

27. Sharma PV. On the origin of person: Wholesome and unwholesome food. Caraka Samhita. Reprint Ed. Varanasi: Chaukhambha Orientalia, Varanasi; 2008. p. 167.

28. Sharma PV. Sutrasthana: On quantity of diet. Caraka Samhita. Reprint. Varanasi: Chaukhambha Orientalia; 2008. p. 33.

29. Sastri A. Sutrasthana. Shushruta Samhita. Reprint. New Delhi: Chaukhambha publication; 2010. p. 82.

30. Sharma PV. Sutrasthana: On the discussion among atreya, bhadrakapya etc. Caraka Samhita. Reprint. Varanasi: Chaukhambha Orientalia; 2008. p. 190-1.

31. Sabnis M. Viruddha Ahara: A critical view. Ayu. 2012; 33(3): 332-6. PMid: 23723637 PMCid: PMC3665091. https:// doi.org/10.4103/0974-8520.108817

32. Sastri K, Chaturvedi Gorakha N. Sutrasthana. Charak Samhita. Varanasi: Chaukhambha Bharati Academy Varanasi; p. 521-3.

33. Veena, Verma V. An appraisal on Ayurvedic diet and dietary intake considerations in view of nutrition science. Indian J Nutr Diet. 2018; 55:88-107. https://doi.org/10.21048/ ijnd.2018.55.1.18007

34. Mishra YC. A text book of Ayurvediya physiology. 1st ed. New Delhi: Chaukhambha Publication; 2008. p. 303.

35. Sharma PV. Vimanasthanam: On Specific Features of Rasa. Caraka Samhita. Reprint ed. Varanasi: Chaukhambha Orientalia; 2008. p. 305-6.

36. Sharma PV. Charak Samhita of Agnivesha. Sutrasthana. Reprint ed. Varanasi: Chaukhambha Orientalia; 2008. p. 32.

37. Sharma PV. Sutrasthana: On non-susppression of urges etc. 32 V, editor. Caraka Samhita. Reprint. Varanasi: Chaukhambha Orientalia, Varanasi; 2008. p. 50.

38. Tiwari P. Sign/symptoms of pregnancy and antenatal care. Ayurvedic Prasutitantra Evam Striroga. Reprint. Varanasi: Chaukhambha Orientalia; 2009. p. 292-3.

39. Sharma PV. On principles of procreation in sarirasthanam. Caraka Samhita. reprint ed. Varanasi: Chaukhambha Orientalia; 2008. p. 466.

40. Tiwari P. Sign/symptoms of pregnancy and antenatal care. Ayurvediya Prasutitantra Evam Striroga. Reprint. Varanasi: Chaukhambha Orientalia; 2009. p. 218-25. PMid: 20049299 PMCid: PMC2800901.

41. Sharma PV. Sarirasthanam. Caraka Samhita. reprint ed. Varanasi: Chaukhambha Orientalia; 2008. p. 473. 
42. Park K. Nutrition and health. Preventive and Social Medicines. 22th ed. Prem Nagar, Jabalpur; 2013. p. 563.

43. Banerjee S, Debnath P, Kumar P. Journal of traditional and complementary medicine ayurnutrigenomics: Ayurvedainspired personalized nutrition from inception to evidence. J Tradit Chinese Med Sci. 2015; 5(4):228-33.

44. Srilakshmi B. Nutrition Science. Fifth. New Delhi: New Age International (P) Limited, Publishers; 2016. p. 518-20. PMCid: PMC5206881.

45. Kalra EK. Nutraceutical-definition and introduction. AAPS PharmSci. 2003; 5(3):E25. PMid: 14621960 PMCid: PMC2750935. https://doi.org/10.1208/ps050325
46. Srilakshmi B. Nutraceuticals. Food Science. Reprint. New Delhi: New Age International (P) Limited, Publishers; 2016. p. $436-49$.

47. Srilakshmi B. Dietetics. Seventh. New Delhi: New Age International (P) Limited, Publishers; 2014. p. 448-50.

48. Srilakshmi B. No Title. Dietetics. 7th ed. New Age International (P) Limited, Publishers; 2014. p. 428.

49. Srivastava RK. Report of the Working Group on Disease Burden for 12th Five Year Plan. New Delhi; 2011.

50. Park K. Community nutriton progams. Preventive and Social Medicines. 22nd ed. Prem Nagar Jabalpur; 2013. p. 612-4. 